$\xi=-1$

\title{
Vertical Integration Market Analysis of Palm Oil Fresh Fruit Bunches in West Sumatera, Indonesia
}

\author{
Lisa Nesti ${ }^{1}$, Firwan Tan $^{2}$, Endrizal Ridwan ${ }^{3}$, Rika Ampuh Hadiguna ${ }^{4}$ \\ ${ }^{1,2,3}$ Post Graduate Program of Economics, Faculty of Economics, Andalas University \\ ${ }^{4}$ Post Graduate Program of Industrial Engineering, Faculty of Engineering, AndalasUniversity \\ *Corresponding author :lisa_nesti@yahoo.com
}

\begin{abstract}
This study aims to examine whether there is asymmetric information on the vertical integration market in palm oil Fresh Fruit Bunches (FFB) in West Sumatera using Error Correction Model (ECM) and analyze the factors causing price inefficiency of oil palm in West Sumatera. The result obtained the change in price of FFB of palm oil of sales realization at agent level, sales realization of export price of crude palm oil (CPO), and sales realization of export price of kernel have positive effect on sales realization at smallholder price of FFB level and Error Correction Term (ECT) value is negative and significant at 5\% of real level, which states that in the short and long run, the free variables used significantly influence the sales realization at smallholder price of FFB of palm oil level. Exporter of CPO is one actor involved in it who has dominant power in influencing the selling price of FFB so that they can manage the selling price of FFB farmers as a producer of palm oil, this is the cause of inefficiencies in the vertical integration market
\end{abstract}

Keywords: ECM, Crude Palm Oil, Fresh Fruit Bunches.

\section{Introduction}

An efficient market maintains the operation of the principles of perfect competitive market, which the economic resources allocation mechanism is based on the interaction of forces of demand and supply. Practically, the ideal condition is never achieved as the market fails to achieve an efficient allocation of resources. This occurs in the market of agricultural industry commodities, especially the palm oil fresh fruit bunches (FFB) of West $\mathrm{Su}-$ matera Province.

West Sumatera Province is still dominated by agriculture, forestry and fishery sectors as the main business field with a contribution to West Sumatera Gross Regional Domestic Product (GRDP) of $23.10 \%$ in 2016, of which the contribution of the plantation sub sector was $6.57 \%$ (17). Oil palm has a great potential to be developed as seen from the total palm oil production of $1,161,039$ tons in 2015, an increase of $0.77 \%$ from 2014. In addition, the plantation area of oil palm also increased from 390,380 Ha in 2014 to $392.315 \mathrm{Ha}$ in 2015 (16).

Although the palm oil commodity has contributed to the GRDP, this agricultural commodity is easily damaged, and therefore must be processed by the consumers in a short time to maintain the quality. Because of this condition, the smallholders do not have any other options to minimize the risk. Therefore, most smallholders sell their products to the collector without considering the price offered. This condition is abused by collectors and palm oil mills that have monopsony or oligopsony power in controlling prices to make a huge profit, by giving inaccurate information between the purchasing price of FFB of palm oil from the collectors and exporters to the smallholders, and the actual standard price applicable in the market at the time, which leads to the inefficiency of palm oil market in West Sumatera. Besides, most exporters in
West Sumatera have their own palm oil FFB processing plant, thus they can dictate the price of palm oil FFB to smallholders. In the domestic market, exporter acts as the price maker, which can be said as one of the reasons why the price at the smallholder level is very low and often fluctuates.

Irawan (1) stated that the vegetable market at farm level tends to be monopsony or oligopsony, while Kustiari (2) found price changes in the world market are not always immediately followed by changes in the domestic market, especially at the smallholder level. It occurs because of government intervention in domestic market, by making basic pricing policy or government purchasing price for grain at the smallholder level. In addition, there are some differences between product characteristic and asymmetric information. Arianto (3) explained that in the long run, CPO is the most influential variable in the vegetable oil market. Mohammadi et al. (4) discovered that price variation is normal in any commodity market. While the price variation is inevitable, the industry can minimize the significant impacts in the system by understanding the structure and the behavior of the market and making decisions of the future price trends possibility. Two key R\&D targets for the palm oil industry are higher oil yield in fruits and trees, higher mesocarp oleic acid composition preferably over $65 \%$ (5).

Some of the methods used to describe the vertical integration market and market integration based on the value of price transmission elasticity is by using simple linear regression (6). The analysis of market integration was performed by using Autoregressive Distributed Lag Model, while (7) analyzed the Indonesian CPO exports using the Two Stage Least Square (2SLS) method. Error correction model (ECM) used to see the long term and short term effects of each independent variable on bound variables. If two variables are not stationary but mutually cointegrated then it can be concluded that there is a long term equilibrium relationship between the two variables. In the short term there is the 
possibility of an imbalance, and to overcome it is used correction with ECM (8).

The purpose of this study is to examine whether there is an asymmetric information on the vertical integration market in FFB of palm oil in West Sumatera Province using ECM and analyze the factors causing price inefficiency of the oil palm commodity in West Sumatera province. The hypothesis of this research is palm oil processing factories as well as exporters, in buying FFB from collectors and then from collectors buy FFB to smallhoders allegedly the workings of inefficient competition market forces in West Sumatera province.

\section{Literature Review}

\subsection{Vertical Integration Market}

The price transmission and the market integration level can be used as indication of the efficiency formed between two interacting markets, both vertically and spatially (9). Market integration is a measure that shows how far the price changes that occured in the reference market can cause price changes in the follower markets (10).

In the long run, commodity prices tend to rise due to the rising of consumer demand. However, the rate of price increase at the consumer level may be different from the rate of price increase at the smallholder level and depends on the trader's behavior in transmitting prices from the consumer to the smallholder. In a perfect competitive market, the trader will continue to ensure every rise in prices at the consumer level is the same amount as at the smallholder level, i.e. the price increase at the consumer level is relatively equal to the price increase at the smallholder level. However, in the market which has monopsony or oligopsony power, the price increase at the smallholder level will be less than the price increase at the final consumer level due to the behavior of traders trying to maximize their profits by providing imperfect pricing information to diminish the purchasing price of the smallholders (1).

\subsection{Market Structure and Efficiency}

Neo-classical economists believe that price is the main indicator which can reflect the level of market efficiency. The level of market integration can be used as an indication of the efficiency of which is formed between the two or more market interacts, either vertically or horizontally (9). Market integration is a measure that indicates how far the price changes in the reference market would lead to the price changes in the follower market. Thus, the analysis of market integration is associated with the analysis of relationships between market structure, market conduct, and market performance. Firwan (11) stated that in many theories of industrial organization and economics reviews, these three aspects are often called as "S-C-P model" (structure-conduct and performance model). The reason is that the conditions of market structure influence simultaneously the condition of market conduct and market performance. Thus, these three aspects cannot be separated of each other in the determining process of price efficiency or marketing efficiency (10). Market integration can be classified into two types, i.e. vertical integrated market system and horizontal integrated market system. Vertical integration is the incorporation process of two or more marketing agencies in the distribution stages into one system management, while horizontal integration is the merger of two or more marketing agencies that perform the same function at the same stage of distribution into a single management system (12).

Price transmission from producer to wholesaler is asymmetric both in the long and short run, vertical price transmission from producer to retailer is asymmetric in the short run, but is symmetric in the long run; from wholesaler to retailer is symmetric in the short run, but is asymmetric in the long run (13). In a perfect competitive market, traders will continue to make every rise in prices at the final consumer level is the same amount as at smallholder levels, i.e. the price increases at the final consumer level is relatively equal to the price increases at the smallholder level. Nevertheless, in the market with monopsony or oligopsony power, the price increase at the smallholder level will be less than the price increase at final consumer level due to the behavior of traders who tend to maximize profits by providing imperfect pricing information to lessen the purchasing price from smallholders (1).

\subsection{Error Correction Model (ECM)}

Error correction model (ECM) is a model used to observe the long and short run effects of each independent variable on dependent variable. ECM is a technique for correcting short-run imbalances towards long-run balances and can explain the relationship between the dependent variables and the independent variables of the present and the past. The ECM model has several uses, but the most important use is to overcome the non-stationary time series data especially palm oil price in West Sumatera Province.

Based on the research by Gujarati (14), the general model of ECM in this study is defined as follows:

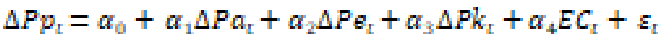

$$
\begin{aligned}
& \text { With: } \quad E C_{r}=P p_{r-1}-\beta_{0}-\beta_{1} P a_{r-1}-\beta_{2} P e_{r \rightarrow 1}-\beta P k_{r \rightarrow 1} \text {, } \\
& \Delta P a_{r}=P a_{r}-P a_{r=1} \quad \Delta P e_{r}=P e_{r}-P e_{r=1}, \Delta P k_{r}=P k_{r}-P k_{r=1}
\end{aligned}
$$

For non-linear regression, by entering log into the equation, it will be:

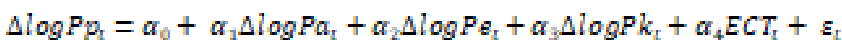
with

$E C_{r}=\log P p_{r=1}-\beta_{0}-\beta_{1} \log P m_{n-1}-\beta_{2} \log P e_{r=1}$.

where $: \Delta \log P_{p_{E}}=$ Difference of sales realization at smallholder price of FFB $(\mathrm{Rp} / \mathrm{kg}), \triangle \log P a_{\mathrm{t}}=$ Difference of price of FFB of sales realization at agent level $(\mathrm{Rp} / \mathrm{kg}), \triangle \log P e_{e_{\mathrm{L}}}=$ Difference of sales realization of export price of $\mathrm{CPO}(\mathrm{Rp} / \mathrm{kg})$ $\triangle \log _{Q} P k_{\mathrm{I}}=$ Difference of sales realization of export price of kernel $(\mathrm{Rp} / \mathrm{kg}), \varepsilon_{\mathrm{r}}=$ Error term,$a_{i}=$ Coefficient of shortrun, $\beta_{i}=$ Coefficient of long-run, $\mathrm{EC}=$ Error Corection Term The efficiency value shown in the regression coefficient in the equation, can be described as follows:

$$
\begin{aligned}
& \Delta \log P_{10}=\log a+b \Delta \log P \\
& \frac{\partial \Delta \log _{P} P_{P}}{\partial \Delta P}=\frac{\partial \log _{2}}{\partial \Delta P}+b \frac{\partial \Delta \log P}{\partial \Delta P}
\end{aligned}
$$

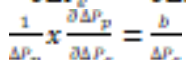

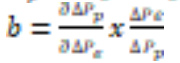

The imbalance correction coefficient $\alpha_{4}$ is an absolute value that explains how quickly the time required to obtain the equilibrium value. If the probability value of the coefficient $\alpha_{4}$ is smaller than 0.05 , it will be indicated to have a short-run relationship.

According to Tukan (15), the implications of the elasticity coefficient $b=E t$ are: [1] Et $=1$, which means that a $1 \%$ price change rate at the buyer level results in a $1 \%$ change in the producer level (smallholders). The prevailing market is perfect competitive market, efficient and symmetrical marketing system in which the price information is fully transmitted to the underlying marketing; [2] Et $<1$, which implies that the rate of price change of $1 \%$ at the buyer level results in a change of less than $1 \%$ at the producer level (smallholders). The prevailing market is imperfect competitive market, inefficient and asymmetric marketing system in which price information is not fully transmitted to the underlying marketing; and [3] Et> 1, which means that the rate of price change of $1 \%$ at the buyer level results in a change of more than $1 \%$ at the producer level (smallholders).

The prevailing market is imperfect competitive market, inefficient and asymmetric marketing system in which price information is 
not fully transmitted to the underlying marketing. Before conducting ECM estimation and descriptive analysis, there are several tests that must be done, i.e. data stationarity test, integration degree test, and cointegration test.

\section{Methods}

This study will investigate whether there is asymmetric information on the vertical integration market that causes the bargaining power of the smallholders to be weakened by modeling the price of FFB of oil palm of sales realization at the smallholder level towards the price of FFB of oil palm of sales realization at agent/collector level, the price of CPO of sales realization of export, and the price of kernel of sales realization of export by using ECM and use classical asumtion test to determine whether there is a deviation from the classical assumption.

\subsection{Data Collection}

The research was conducted in West Sumatera, Indonesia by using primary and secondary data. Purposive sampling of time series data was used to develop the model of the market or business actors behavior in producing and marketing activities in the marketing chains from oil palm smallholders to agents or wholesalers, and exporter producer of CPO. The secondary data obtained was from several goverment institutions such as the Central Bureau of Statistics, West Sumatera Plantation Office, West Sumatera Trade and Industry Office, West Sumatera Custom Office, mass media and related online media of oil palm plantation and trading. This research used quantitative and descriptive analysis. The data used in this study were the monthly data starting from 2010 to July 2017, which means that the number of observations equals to 90 $(n=90)$. Secondary data includes selling prices of FFB of oil palm to smallholders, agents or wholesalers, CPO at the exporter level price, and kernel at the exporter level price.

\section{Result and Discussion}

This section, will disscuss the classical assumtions which consist of multicollinearity, heteroscedasticity, normality, and autocorrelation tests. Subsequently, the ECM regression analysis was performed accordingly.

\subsection{Classical Assumption Test}

This test is used to determine whether there is a deviation from the classical assumption before performing the ECM regression analysis. the result are multicollinearity, heteroscedasticity, normality, and autocorrelation tests :

1) Multicollinearity : If in a regression model found the existence of multicollinearity then the regression model can not be used. To test whether or not multicollinearity can use partial correlation method between independent variables.

\begin{tabular}{|c|c|c|c|c|}
\multicolumn{7}{|c}{ Table 1. Multicollinearity Test } \\
\hline & $\mathrm{C}$ & $\log (\mathrm{Pa})$ & $\log (\mathrm{Pe})$ & $\log (\mathrm{Pk})$ \\
\hline $\mathrm{C}$ & 1 & 0.0019 & -0.0076 & 0.0008 \\
\hline $\log (\mathrm{Pa})$ & 0.0019 & 1 & -0.0025 & -0.0004 \\
\hline $\log (\mathrm{Pe})$ & -0.0076 & -0.0025 & 1 & -0.0001 \\
\hline $\log (\mathrm{Pk})$ & 0.0008 & -0.0005 & -0.0001 & 1 \\
\hline
\end{tabular}

Based on Table 1 that the obtained partial correlation coefficient between independent variables is relatively low, below 0.8 . Hence, it has no symptoms of multicollinearity between independent variables.

2) Heteroscedasticity test : A regression problem whose error does not have the same variant that causes the OLS estimator to be biased. The method used to test heteroskedasticity here using the Pagan-Godfrey-Breusch test. If value Obs $* \mathrm{R}$ square $>5 \%$, it can be concluded that the regression model has no problem of heteroskedasticity in the ECM model.
From the Pagan-Godfrey-Breusch test (Table 2), it can be seen that $\mathrm{Obs} * \mathrm{R}$-square value of 7.749412 is greater than $\alpha$ $=5 \%$. Thus, it can be concluded that the regression model used has no heteroscedasticity problem.

Table 2. Heteroskedasticity Test Heteroskedasticity Test: Pagan-Godfrey-Breusch

\begin{tabular}{|l|r|l|l|}
\hline & & & \\
\hline F-statistic & 2.700890 & Prob. F(3,86) & 0.0506 \\
\hline Obs*R-squared & 7.749412 & Prob. Chi-Square(3) & 0.0515 \\
\hline Scaled explained SS & 66.90308 & Prob. Chi-Square(3) & 0.0000 \\
\hline
\end{tabular}

3) Autocorrelation Test The test results for autocorrelation shows that the Chi-square probability value of 0.1680 is greater than $\alpha=5 \%$. (Table 3 ). Thus, the model contains no autocorrelation.

Table 3. Autocorrelation Test

\begin{tabular}{|l|r|l|r|}
\hline Breusch-Godfrey Serial Correlation LM Test: & \\
\hline & & & \\
\hline F-statistic & 1.733815 & Prob. F(2,84) & 0.1829 \\
\hline Obs*R-squared & 3.568026 & Prob. Chi-Square(2) & 0.1680 \\
\hline
\end{tabular}

4) Normality Test : PP-Plots are used to test whether the data is normally distributed or not. If the distribution of the points approaches a straight line then it can be concluded that the data used in the ECM model is normally distributed. Figure 1 shows the data to be normally distributed.

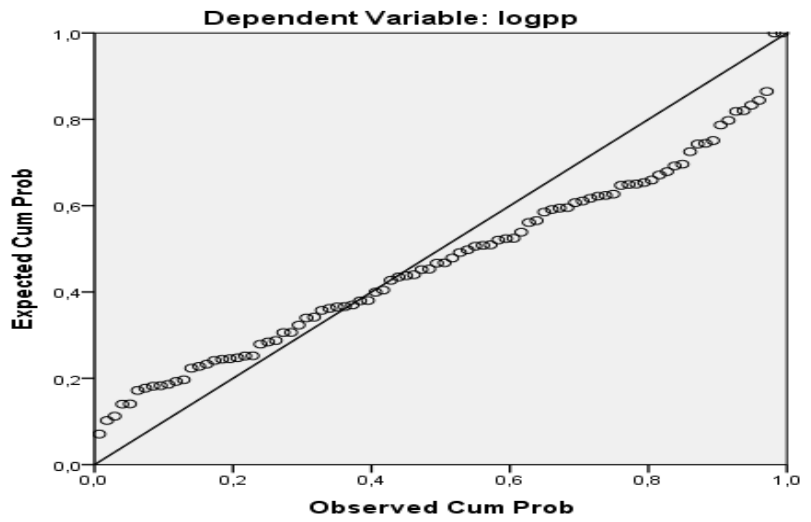

Figure 1. Normality Plot

5) Linearity Test : Linearity test is done by using Ramsey Reset test by comparing the value of the $\mathrm{F}$ statistic with $\mathrm{F}$ table. If $\mathrm{F}$ statistic is greater than $\mathrm{F}$ table, with $\alpha=5 \%$, then the value of critical $\mathrm{F}$ at a certain level of significance. Table 4 shows that the F statistic of 0.6704 is greater than $\alpha=5 \%$. The researcher concluded that the model developed can assess the influence of the price of FFB of oil palm of sales realization at agent level, price of crude palm oil (CPO) of sales realization of export and domestic price of CPO, sales realization of export and domestic price of kernel have positive effect on sales realization at smallholder price of FFB level.

Table 4. Linearity Test

\begin{tabular}{|l|c|c|c|}
\hline \multicolumn{4}{c|}{ Table 4. Linearity Test } \\
\hline & Value & df & Probability \\
\hline t-statistic & 0.427028 & 85 & 0.6704 \\
\hline F-statistic & 0.182353 & $(1,85)$ & 0.6704 \\
\hline Likelihood ratio & 0.192872 & 1 & 0.6605 \\
\hline
\end{tabular}

\section{Error Correction Model}

Before performing ECM regression, the variables used need to be confirmed to be stationary or non-stationary by using unit root test with Augmented Dicky Fuller (DF) method. The result of the test can be seen in Table 5

Table 5. Unit Roots Test

\begin{tabular}{|l|l|l|l|l|}
\hline \multirow{3}{*}{ Variable } & \multicolumn{4}{|l|}{ Unit Roots Test } \\
\cline { 2 - 5 } & Level & $1^{\text {st }}$ Difference \\
\cline { 2 - 5 } & ADF & Prob & ADF & Prob \\
\hline $\log (\mathrm{Pa})$ & $-3,80$ & 0,0041 & $-11,76$ & 0,0001 \\
\hline
\end{tabular}




\begin{tabular}{|l|l|l|l|l|}
\hline $\log (\mathrm{Pe})$ & $-3,13$ & 0,0278 & $-9,97$ & 0,0000 \\
\hline $\log (\mathrm{Pk})$ & $-2,35$ & 0,1581 & $-8,74$ & 0,0000 \\
\hline $\log (\mathrm{Pp})$ & $-2,37$ & 0,1520 & $-8,09$ & 0,0000 \\
\hline
\end{tabular}

From unit root test with Augmented Dickey Fuller which use $1^{\text {st }}$ Difference method, all variables are stationary at 5\% of real level, so it is stated that the data is stationary at $1^{\text {st }}$ Difference and the research was then continued to cointegration test.

The result of OLS regression is obtained as follows:

$\log (P p)=-0,502135+0,557426 * \log (P e)+0,288554 * \log$

From the regression equation, the residual was determined and referred as Error Correction Term (ECT). Subsequently, unit root test with Augmented Dickey Fuller method at the Level was conducted. The residual must be stationary at the Level to be said to have cointegration. The result of unit root test for ECT shows that stationary residual at the Level is represented by Prob value < 5\% (Prob 0,0000), thus it can be stated that the data is cointegrated.

Since ECT is proven to be stationary at the Level, the formation of ECM dynamic regression equation can be continued. The results of ECM analysis are presented in Table 6.

Table 6. ECM Regression Coefficients Of FFB Of Oil Palm and CPO Prices In West Sumatera Province

\begin{tabular}{|l|l|l|l|l|}
\hline & & & & \\
\hline & & & & \\
\hline Variable & Coefficient & & & \\
\hline & & & & \\
\hline & & & & \\
\hline $\mathrm{C}$ & 0.000664 & 0.001803 & 0.367925 & 0.7139 \\
\hline $\mathrm{D}(\log (\mathrm{Pa}))$ & 0.198578 & 0.043735 & 4.540462 & 0.0000 \\
\hline $\mathrm{D}(\log (\mathrm{Pe}))$ & 0.330386 & 0.073024 & 4.524362 & 0.0000 \\
\hline $\mathrm{D}(\log (\mathrm{Pk}))$ & 0.171197 & 0.039705 & 4.311697 & 0.0000 \\
\hline ECT(-1) & -0.071876 & 0.064684 & -1.111178 & 0.0269 \\
\hline & & & & \\
\hline & & & & \\
\hline R-squared & 0.691580 & Mean dependent var & 0.001653 \\
\hline Adjusted R- & & & & \\
squared & 0.676535 & S.D. dependent var & \\
\hline F-statistic & 45.96781 & Durbin-Watson stat & 0.029550 \\
\hline Prob(F-statistic) & 0.000000 & & & \\
\hline & & & & \\
\hline
\end{tabular}

The ECM regression model is presented as follows:

$D(\log (P p))=0.000664+0,198578 * D(\log (P a))+0,330386 * D(\log (P e))$ $+0,171197 * D(\log (P k)-0,071876 * E C T(-1)$

The result of the estimation illustrates that in the short run, the change in price of FFB of oil palm of sales realization of agent level, price of Crude Palm Oil (CPO) of sales realization of export, and sales realization of export price of kernel have positive effect on price of FFB of oil palm of sales realization at smallholder level, ceteris paribus. Furthermore, the value of ECT is negative and significant at $5 \%$ of real level, which states that in the short and long run, independent variables used in this study significantly influence on sales realization at smallholder price of FFB level. $\mathrm{R}^{2}$ value of $67.7 \%$ states that the independent variables included in this model is good to explain the dependent variable and $32.3 \%$ of $\mathrm{R}^{2}$ value is influenced by other variables in the model.

The regression coefficient of each independent variable in the ECM logarithmic dynamic regression model shows the value of price transmission elasticity, which represents the efficiency of the FFB of palm oil marketing system in West Sumatera Province. The ECM regression equation shows that all regression coefficient values of each independent variable are positive, indicating that the price transmission elasticity is greater than $1(\mathrm{Et}>1)$ and can be interpreted as follows:

a) Coefficient $\mathrm{Pa}=0.19857$, states that if there is a change in the price of FFB of oil palm of sales realization at the level of agent of $1 \%$, it will result in sales realization at smallholder price of FFB level is greater than $1 \%$.

b) Coefficient $\mathrm{Pe}=0.330386$, states that if there is a change in the price of CPO of sales realization of export of $1 \%$, it will result in sales realization at smallholder price of FFB level greater than $1 \%$. c) Coefficient $\mathrm{Pk}=0.171197$, states that if there is a change in sales realization of export of kernel of $1 \%$, it will result in sales realization at smallholder level price of FFB level is greater than $1 \%$.

d) Coefficient of ECT $=-0.071876$, states that the difference in the price of FFB sales realization at smallholder price of FFB level with an equilibrium value of 0.071876 will be adjusted within one year.

The market condition is not profitable for the smallholders because the traders who have the monopsony power will control the price. Hence, smallholders tend to receive low prices due to the behavior of traders who seek maximum profits, thus the price changes that occur at the consumer level is not fully transmitted to smallholders (Asymetric Information). On the other hand, the marketing conditions are said to be efficient if they can provide maximum satisfaction for producers, consumers and the marketer involved.

\section{Factors Causing Price Inefficiency of the Oil Palm in West Sumatera Province}

In West Sumatera province, there are 13 exporters of CPO, 12 exporters have their own factory, 9 exporters own factory and own garden, only 3 exporters have no factory and garden (exporter only). As such, most of the exporters have a dual role that is in addition to be an exporter of CPO abroad, the exporters also produce and simultaneously process the FFB into CPO. Two CPO companies are only shipping CPO for domestic usage to Java Island and other islands in Indonesia. Exporters of CPO are exporting through Teluk Bayur port with main destination countries to India, China, Singapore and Europe. CPO exporters are sending $\mathrm{CPO}$ based on contract agreements with overseas traders that include agreement on the selling price of CPO, the amount of CPO to be shipped, specifications and type of payment. Judging from the company's ownership status, 10 exporter companies (or around $80 \%$ ) are controlled by Incasi Raya Group as the largest exporter company in West Sumatera by exporting CPO products produced by companies ranging from $75 \%$ and only $25 \%$ used as raw material for cooking oil for domestic consumption (West Sumatera, Jambi, Bengkulu and Riau), with a fixed amount depending on the remaining CPO exports. The company prioritizes $\mathrm{CPO}$ exports rather than making cooking oil because from the interviews obtained information that by exporting overseas, the cash flow quickly, the company can sell in large parties so that profits are obtained larger and faster. While other large companies prioritized domestic CPO shipments as raw materials for CPO derivative products processing plants that are still incorporated in one group of companies located in Medan and Dumai, some of them also produce olein (cooking oil) which is sent to a packing plant of cooking oil which is still incorporated in a group outside of West Sumatera.

If viewed from the purchase price of FFB made by the team formulation of prices facilitated by the Office of Food Crops, Horticulture and Plantation West Sumatera Province on companies that partnered with the farmers of the plasma scheme in the area that has been determined that done every two weeks. It can be seen that the price determination of FFB is strongly influenced by the average price of CPO weighted realization of export sales as well as influenced by the average price of $\mathrm{CPO}$ weighted realization of local sales of each exporting company, as previously described that companies doing CPO exports in West Sumatera is 10 out of 13 export companies incorporated in the Incasi Raya Group, so that by itself the price of realization of export sales of CPO exporter companies incorporated in the Incasi Raya Group is very dominant in the CPO price determination realization selling export. Thus, it can be said that the structure of export market in West Sumatera province is oligopsony market which is dominated by the Incasi Raya Group where from the average export volume of CPO of $93 \%$ from 2014 to 2017. This shows that more than 90 $\%$ of the CPO production of West Sumatera exported abroad and 
Incasi Raya Group is more dominant with market share of more than $90 \%$.

As such, the researcher had proven that the role of exporter is very big in determining the price of FFB farmers. However, the price obtained from the price fixing can only be applied to smallholders, whereas for independent farmers it is always below the farmers of the plasma scheme price after several collectors. As a result, the price received by independent farmers can be half the price at the farmers of the plasma scheme, here the plasma farmers can not bargain the price because the selling price has been set by the collector and the price of the collector's price has been determined by the factory. The presence of asymmetric information and oligopsony market structure in the FFB market in West Sumatera Province has been proven.

\section{Conclusion and Recommendation}

There is an inefficiency in the selling price of FFB of palm oil in West Sumatera province as seen from the measurement of the price efficiency based on Error Correction Model. It is generally stated that the FFB of oil palm and CPO in West Sumatera Province are in imperfect competition markets which leads to a monopsony or oligopsony, and market systems are currently inefficient.

This research recommends the government's role in monitoring and controlling the selling price of FFB not only at the farmers of the plasma scheme but also at smallholder level so that the farmers income can be improved and the farmers FFB can compete with the better quality of FFB. As the vertical integration market closely related to the supply chain, it is necessary to make the supply chain effective. This involves all actors in the supply chain of FFB in West Sumatera Province from upstream to downstream by mutual cooperation in the form of transparent price information delivery, so that $\mathrm{CPO}$ price increase in international market, can be enjoyed by all the actors particularly the smallholders.

\section{Conflict of Interest}

The conflict of interest occurring in the vertical integration market of oil palm in West Sumatera Province, that can be found is one actor involved in it has dominant power in influencing the selling price of FFB so that he can manage the selling price of FFB farmers as a producer of palm oil, consequently the farmer is always on weak bargaining power while on the other hand oil palm entrepreneurs benefit greatly from the FFB sales activity.

\section{Acknowledgments}

We would like to thank Polytechnic ATI Padang and Andalas University as the parties involved in this research and funding activities so that this research can be completed.

\section{References}

[1] Irawan, B. (2007). Price Fluctuations, Price Transmission, and Margin of Vegetables and Fruit Marketing. Journal of Agricultural Policy Analysis, volume 5, issue 4, December 2007: 358-373

[2] Kustiari,R., \& Nuryati, S. (2008). Dynamics of Agricultural and Rural Development: Challenges and Opportunities for Increasing Farmers' Welfare. Centre for Agricultural Socio Economic and Policy Studies, Department of Agriculture. Bogor

[3] Arianto, E. (2010). Analysis of Palm Oil Price, Review of Cointegration of Vegetable Oil and Petroleum Price. Journal of Bogor Institute of Agricultural. Volume 7, issue 1.

[4] Mohammadi, S., Arshad, F M., Bala, B. K.,\& Ibragimova (2015) System Dynamic Analysis of the Determinants of the Malaysian Palm Oil Price. American Journal of Applied Sciences 12(5): 355362.
[5] Murphy, D. J. (2014). The Future of Oil Palm As A Major Global Crop: Opportunities and Callenges. Journal of Oil Palm Research Vol. 26 (1) March 2014 p. 1 - 24

[6] Rahmi, E., \& Arif, B (2012). Analysis of Corn Price Transmission as Chicken Feed Ingredients in West Sumatera. Indonesian Journal of Animal Science.

[7] Abidin, Z. (2008). Analysis of Indonesian Crude Palm Oil (CPO) Exports. Journal of Management Application, volume 6, issue 1. Faculty of Economics, University of Brawijaya.

[8] Engle, Robert F. and C.W.J. Granger, (1987). Cointegration and error correction: Representation, estimation and testing, Econometrica $55,251-276$

[9] Meyers, R.A. (2011). Complex Systems in Finance and Econometrics. 1st Edn., New York, Springer, ISBN- 10: 1441977007.

[10] Asmarantaka. (2009). Lecture Module of Trading System of AgroIndustry Product. Department of Agro-Industry, Faculty of Economics and Management, Bogor Institute of Agriculture. Bogor.

[11] Tan, Firwan. (2005). Price Efficiency at Vertical Integrated Market Study on Market of Natural Rubber Industry Products of Indonesia. Journal of Management and Development, Volume 4, issue 1.

[12] Kusnadi, N., Tinaprilla, N., Susilowati, S. H \& Purwoto. (2011). Analysis of the Efficiency of Rice Farming in Several Rice Production

[13] Karantininis, K., Katrakylidis, K \& Persson, M. (2011). Price Transmission in The Swedish Pork Chain: Asymmetric Non-Linear. Paper Presented at The Eaae 2011 Congress. 2011

[14] Gujarati, D. (2003). Basic Econometrics, translation of Sumarno Zain. Erlangga, Jakarta.

[15] Tukan, C. J. (2001). Marketing of Wood from Farmer's Land in Lampung Province.http://www.worldagroforesty.org. Master of Development Studies, Bandung Institute of Technology.

[16] West Sumatera Plantation Office. 2015

[17] West Sumatera Province in Figure. 2017. Central Bereau Statistics of West Sumatera Province 